\title{
Peace Forged by Warfare: The Universal Declaration of Human Rights 70 Years After
}

\author{
Thiago Rodrigues* \\ Tadeu Maciel ${ }^{* *}$ \\ João Paulo Duarte ${ }^{* \star *}$
}

\begin{abstract}
The $70^{\text {th }}$ anniversary of the Universal Declaration of Human Rights (UDHR) in December 2018 created a need to problematise its precepts and their political consequences in contemporary times. Drawing on Michel Foucault's genealogical approach to power, this article analyses the normative inscription of the UDHR as the emergence of a juridical-political device that produces new modulations of biopolitics. As such, it is not based on peace, as is commonly argued, but on the permanent reinscription of war, sometimes in dimensions that go beyond the boundaries of sovereignty.
\end{abstract}

Keywords: Universal Declaration of Human Rights; politics as warfare; biopolitics; re-inscription of war; Foucauldian analyses.

\section{Introduction}

Since the mid-1970s, the Universal Declaration of Human Rights (UDHR) has played an increasingly prominent role in international attempts to address the issue of human dignity. Adopted by the United Nations General Assembly in 1948, the UDHR, alongside other documents and protocols that rose from the ashes of World War II, formed a concert of juridical-political devices aimed at promoting a permanent peace. As such, it gained a high level of recognition and legitimacy, and became a standard framework for defining global 'human rights.'

Despite the grandiloquent speeches glorifying the UDHR at the time, it was not conceived in some kind of ideal and timeless space but in a specific historical context, which

* Fluminense Federal University (UFF), Niterói-RJ, Brazil; th.rodrigues@gmail.com. ORCID iD 0000-00020962-0391.

** Fluminense Federal University (UFF), Niterói-RJ, Brazil; tadeummaciel@gmail.com. ORCID iD 00000003-2591-4557.

*** Paulista University (UNIP), Santos-SP, Brazil; joaopgpd@gmail.com. ORCID iD 0000-0001-9941-717X. 
eventually influenced its contents. Following World War II, the victorious powers sought to establish a new global political and economic order. As a result, besides its normative dimensions, the UDHR was rooted in a search for a new balance of power, not only in military and economic terms, but also in terms of a new set of values that could serve as a common ground for a 'new era.'

Paradoxically, the UDHR has been understood as a secular version of the 'Ten Commandments' on the one hand, and a covert attempt to support global submission to US hegemony on the other (Moyn 2010). However, the debates between its defenders and critics have failed to deal with an important issue, namely the values that have developed around the UDHR since the 1970s which have, in turn, produced the institutions, social practices, political constraints and processes of subjectification underpinning current power arrangements in international politics. In other words, concepts such as 'human,' 'humanity,' 'peace,' 'rights' and 'universality' have become 'unquestionable truths' that are under attack from authoritarian positions in Brazil, Hungary, the Philippines and the USA which dismiss human rights as 'globalism,' or a 'liberal imposition of values.'

In order to get beyond the 'for' or 'against' dichotomy, this article considers the UDHR as a historical construct - that is, a political instrument for producing a specific model of human and institutional relations, and an area of combat where a myriad of power relations, antagonistic values and social practices collide in order to establish novel forms of social control - but also innovative means for subjected people to struggle for liberation.

Drawing on Michel Foucault's notion of the genealogy of power, we aim to examine the basic set of arguments that identifies the UDHR as a product of reason and common sense, and a form of civilizational reach that ultimately recognises a universal human dignity. First, we intend to examine the issue of 'warfare' as the main driver of the Declaration. Instead of identifying 'peace' as the main driver, we stress the role of the 'politics of force.' This 'perspective of war' is related to the Foucauldian notion of 'politics as warfare' (Foucault 2003), and the defeat of some forms of knowledge and practice by other sets of values. We also invoke an interpretation of the formulation of norms and institutions centred on the work of Pierre-Joseph Proudhon, especially his book War and Peace, first published in 1861, in which he argued that 'warfare is the main legislator' (Proudhon 1998 [1861]: 45). In other words, legal codes, cultural standards, scientific truths, religious dogmas and so on do not reveal a previously hidden 'Truth', but manifest values belonging to the victor. In this view, the UDHR is simultaneously a response to the genocides of World War II, a product of its victorious powers, and a way of imposing novel global parameters for human conduct.

As will be discussed below, the Foucauldian notion of 'politics as warfare' resonates with Proudhon's concept of the 'right of might' (droit de la force) and the Foucauldian perspective of véridiction, a neologism based on 'vérité (truth), which Foucault used in his later work to identify the process in which discourses about what is 'true' or 'false' are produced within complex disputes around what is and is not credible (Foucault 2008; Siisiäinen 2019). In our context, it enables us to ask how the UDHR has become a statement of the 'truth' about 'humanity', and the forces and practices this 'vérité' could release in respect of the conduct of states, other institutions, and individuals. 
In this context, we argue that the UDHR guides practices of government - even violent ones, such as humanitarian interventions - that reshape 'biopolitics', or the general dynamics of human life (Foucault 1978), extending it beyond state boundaries.

We begin by situating politics, law and rights (including human rights) in war, including its formation, affirmation, negation and transformation. Next, we point out the various provenances of human rights and their emergence from the UDHR. Following this, we examine the UDHR as a contemporary modulation and global projection of biopolitics. Lastly, we examine the tactical and momentary appropriation of human rights as a possibility of resistance (Golder 2015) in a global politics tainted by authoritarianism and an intolerance of lifestyles and values regarded as inimical to a standard morality rooted in conservative religious dogmas and nationalist claims for community survival.

\section{Warfare as legislator}

Foucault's notes on his genealogy of power made during the mid-1970s highlighted the analysis of juridical-political discourses and their relations to the formation theory of sovereignty, as inherently connected to the formation of a modern Western form of government over peoples and territories. According to Foucault (2003), discourses about the state and its associated legal framework are exemplars of the process of véridiction engaged in by philosophers and thinkers gathered around the Western European royal courts, dedicated to naturalising the existence of centralised political power (the state) as the only possible way of avoiding violence, robbery and chaos. Narratives such as Thomas Hobbes's $17^{\text {th }}$ century Leviathan argued that civil peace could only be achieved by unifying political power under the sovereign, who would be able to maintain order within a given realm (Hobbes 1968).

Walker (1992) and others have highlighted that Hobbes and other contractualists such as John Locke, Jean-Jacques Rousseau and Immanuel Kant - were all committed to the state as the only institution capable of securing peace, order, and the protection of private property and individual life. Prior to any considerations of the quality or characteristics of the state/regime (whether absolute monarchy, republic, or constitutional monarchy), the contractualist argument is based upon the binary division of reality into a realm of peace and order and a field of chaos and anarchy. The former is secured by the state authority, and the latter exists outside state borders in a dangerous space called the international (Walker 1992). This is Walker's well-known distinction between the inside, understood as a peaceful space, and the outside, taken as the realm of the constant menace of war.

Foucault barely mention facts or debates that could be directly related to International Relations problematics - except, notably, for his 1978 lectures at Collège de France on 'Security, Territory, Population' and his 1979 articles on the Iranian Revolution (Foucault 2007, 2019; Ghamari-Tabrizi 2016). However, his criticism of the very foundations of the contractualist rationale has been a fertile field for contemporary IR theorists (Walker 1992, 2012; Bonditti et al 2017; Rodrigues 2010). 
What all these authors find most interesting is the possibility of regarding the rigid distinction between war and peace as a common ground for the traditional IR schools, with both Realists and Liberals constructing war/warfare as an exclusively 'international' phenomenon conducted by states and subjected to their political aims. As a corollary, war/warfare is exiled beyond the borders of politics to the realm of international relations. Carl Von Clausewitz (1780-1831), the great theorist of Western warfare, also reproduced these narratives by adapting them to military studies when war, expelled from the space of political normality, occurs internationally as an 'extension of politics', or an instrument available to the state for conducting its foreign relations (Clausewitz 2007).

Despite recognising the relationship between war and politics, this view - famously encapsulated in the Clausewitzian aphorism that 'war is a continuation of politics by other means' - did not allow the regular presence of war within state borders (Foucault 2003). On the contrary, for Foucault, it reinforced the juridical-political arguments which restrict the relation between politics and war. In the course of doing so, it helped to conceal the proper function of political power by perpetually reinserting the relations of force present in war into the regular mechanisms of political institutions. This mechanism is responsible for continuing the relations of domination, force and power in what is conceived as 'civil peace.' In Foucault's words, it worked as another articulated narrative to conceal that 'politics is the continuation of war by other means' (Foucault 2003: 16). Thus, the exercise of politics reinstates a silent and permanent war within the language and institutions of forged and imagined political normality.

This leads necessarily to Foucault's first observation cited above: since politics is a manifestation of war, the state is not born from the interruption of conflicts, but the reshaping of war. Taking the British $16^{\text {th }}$ and $17^{\text {th }}$ historical-political discourses that allow us to correctly conceive of politics as permanent war, Foucault (2003) also notes that laws/ norms are not the result of spontaneous agreements between men to overcome the perpetual war against their neighbour (the 'social contract' present, with some minor differences, in Hobbes, Locke, Rousseau and Kant). On the contrary, according to Foucault (2003), laws are born from battles and massacres, and the imagined 'social order' operated by the law is the result of those confrontations and consequent subjugations and not from consensual pacifications. Objectively, this is a second observation that leads him to propose that war not only presided over the birth and establishment of the state, but also over the continuity of states themselves.

Following this proposition, it is possible to point out how the legal principles and guidelines that govern human relations do not result from peaceful consensus presided over by human reason and common sense, but from wars, conflicts and battles that provide the frameworks for 'peace treaties', criminal codes, civilian norms, and so on. According to this critical review of contractualism, it is also possible to argue that there is no transcendent and universal source of Justice and the law, whether human nature or divine providence. Frédéric Gros is one of the current IR theorists who make similar points about the relationship between politics, war and law. Based on the neglected text by the anarchist philosopher Pierre-Joseph Proudhon entitled War and Peace - which appeared 
in 1861, and provided the title for Tolstoy's eponymous novel - Gros (2010) also seeks to understand war as a founding force that shapes norms and institutions.

For Gros, modern and contemporary humanitarianism cannot accept the 'monstrous idea' that force is the mother and father of all the rules that shape our ordinary life. In this close analysis of Proudhon's statement that Justice is but the dignity of force, Gros argues that the 'rule of law' is merely an empirical manifestation of war and its aftermath. Therefore, 'the founding war of a state law is, then, the idea, first of all, that every system of law rests on its origin in a coup d'état; every rule of law began in and by violence' (Gros 2010: 132). This manifestation is not puerile but permanent because, according to Gros, between war and the rule of law there is not only a relationship of provenance, but also one of the present and the future - that is, a triple temporal dimension in which the presence of war in law can be verified.

This perspective can also be used to draw a parallel with international law, which also carries with it the elementary provenance of war enveloped by an image of peace and agreement. Following Anghie (2007), among others, it is possible to show that, in international law, there is no unanimous and peaceful consent between the parties at the moment of a legal consecration. Since at least the Treaty of Versailles in 1919, the inscription of a right of conquest is pronounced or narrated as a right arising from the last and definitive war, always the darkest and most violent, which ultimately imposes a universal and timeless justice. This conceals the role of force in fixing the parameters of 'justice' that guide the permanent hierarchies in international relations.

Analogous to the principles of sovereignty, human rights were transformed into legal principles regarded as 'solid truths', making both of them susceptible to a similar problematisation. Although politically linked to legal representations that activate notions of 'humanity', it is remarkable to trace the extent to which war and its consequences - notably a recent political and military victory - play a defining role in definitions of 'human rights.' Thus, having its major emblem in the French Revolution, especially the Declaration of the Rights of Man and Citizen of 1789, human rights should not be conceived as a strict product of the Enlightenment aimed at glorifying 'human values' (Hunt 2008), but rather as the product of real struggles and confrontations whose most evident marks, in this case, were the gallows and cadavers of the Revolution. Therefore, beyond their glorification, it becomes possible to recognise elements that associate human rights with the establishment of bourgeois legislation, producing a notion of citizenship which is a form of subjectification proper to capitalist and liberal societies.

When the issue is the UDHR, the presence of war and its legislative force is even more overwhelming. Following the annihilation of more than 60 million people in the fiercest conflict in world history, the production of a new order brought with it a novel project of 'Man.' If the socialist victor, the Soviet Union, had its model of 'humanity' (the abnegated and devoted revolutionary), the Western powers, notably the USA, had their own, based on qualities such as loyalty, individualism, subjection to democratic regimes, and so on. The UDHR, as we will discuss below, belongs in this particular historical context in which a major war opened up space for the construction of a new project for global politics, international economy, and a universally recognised Humanity. 


\section{The UDHR and its warrior's ground}

The solemnity that marked the proclamation of the UDHR at the Palais de Chaillot in Paris on 10 December 1948 (at a session of the United Nations General Assembly) contrasted with the still recent memories of the Nazi occupation. One of the terrains of the terrible confrontations of World War II, Paris symbolically hosted the final activities of the UN Human Rights Commission that resulted in the signing of the document. It was characterised as the most important and comprehensive legal recognition of the dignity of all members of the human family (Hunt 2008). However, the adages and exaltations that accompanied the document can also be seen as instruments that veiled the forces involved in its production. This record pronounced as a right against the marks of war can also be read as a formal but also silent declaration of 'war' amid the return of peace.

Besides the elementary evidence of the relations between the Declaration and the consequences of World War II - already identified by Henkin (1990) and others, who characterise the document as a legal mechanism corresponding to the human extermination in the course of the conflict - an analysis of its legal and political provenance supports this approach. According to Schindler (1979), although the Declaration supposedly belonged to a different branch of the law from that dedicated to the problems of war (the so-called jus in bello), it finds in international humanitarian law one of its more important correspondences. Many of its guidelines overlap with or complement those aimed at fostering humanitarian defence in armed conflicts (Kolb 1998).

Examining this aspect of the Declaration is important. Although it evokes the supposed recognition of human dignity in the occurrence of wars, the norms underpinning International Humanitarian Law (IHL) - born in the second half of the $19^{\text {th }}$ century - emanated from the strategic interests of political actors and movements in Europe.

Due to the revolution in military technology in that period, these movements began to realise just how damaging conflicts on the continent could be. Like the International Committee of the Red Cross (ICRC), they required the utilitarian and selective defence of people involved in wars, associated with the proclamation of humanitarian speeches and claims based on the alleged progress of civilization. In other words, this was a humanitarian defence based on political calculations that predicted: 1) large investments in establishing national armies; 2) the potential death or disability of large numbers of citizen-soldiers, and 3) the importance of articulating humanitarian arguments, intermediate to militarism, in the face of the emergence of international workers' organisations in Europe that began to question nationalism and war, especially with regard to their participation in the conflicts (Duarte 2019). Therefore, these movements articulated the grandiloquence of humanitarian discourses and practices in order to respond to new political emergencies arising from some wars. This dynamic is even related to the rise of German power, which was beginning its industrial revolution and the unification of territories, both rooted in and boosted by the development of a strong industrial-military complex (Gumpert 1944).

In these terms, although allegedly universal, the predictions of IHL, as an essay on the idealization of civilized war, were restricted to Europe, and did not deviate from the racist perspective that drove the colonialism of European countries. It is no accident that some 
items in the Bulletin of the International Committee of the Red Cross at that time, such as 'La Croix-Rouge chez les nègres' (1880) and 'Les insurrections dans l'Afrique austral' (1881), reflect this political circumscription of the humanitarian impulse. They contain terms such as 'savages,' 'barbarians' and 'civilizing aspiration' to affirm the supposed inability of African peoples to adhere to the laws of war, restricting IHL predictions to civilized peoples. This process was guided by an attitude which expressed itself in the political demarcation of a utilitarian and selective humanitarian defence, directed at the reduction of the damage caused by certain wars and to certain humans as well.

The process that culminated in the UDHR was determined by similar strategic political interests, and similarly immersed in the dynamics of colonialism. Consequently, in providing a legal-political counterpoint to the alleged crimes against (European) humanity, the UDHR can also be analysed as a device that, in line with the effects of war, focuses on a utilitarian and selective defence of life. With Europe destroyed not only economically and socially, but also politically and morally, the legal inscription of such an instrument was needed to renew its humanitarian legitimacy, based on a reaffirmed notion of civilizational progress that avoided the colonial vocabulary but was still based on a Western standpoint in terms of values and norms. In this sense, the effort made by the Red Cross to associate the UDHR with humanitarian conventions is symptomatic. However, it is also important to highlight what the ICRC did not mention, namely that the UDHR did not inscribe peoples' right to self-determination. Therefore, it also signalled the direction of its guidelines to an urgent political need, previously identified by supporters of IHL, to establish instruments of law that contemplated the defence of a particular way of life.

According to Mutua (2001), this characteristic of the document signals a particular interpretation of human rights, explains a connection between the UDHR, which coincided with the judgments in the Nuremberg trials, and the consequences of Nazism. For Mutua (2001), the Fascist experience generated the uncomfortable feeling of living in the midst of manifestations of barbarism - notably the Holocaust, perpetrated by a white European government against other white people (predominantly Jews) on European soil. There was no elementary consideration by European political representatives that such practices were established features of colonisation by various European powers, such as the enslavement, exploitation and extermination of African peoples (Mbembe 2003). In this sense, the emergence of the UDHR can be understood as a political contingency rather than a sudden understanding of human dignity.

This also points to the importance of analysing the political context in which the Declaration was developed. It started because the US government wanted to insert human rights considerations into its foreign policy investments. As noted by Comparato (2013), this is especially evident from President Franklin D. Roosevelt's famous 'Four Freedoms' speech in 1941 in which he listed the principles that should guide US policy in the postwar world. These four freedoms - freedom of speech, freedom of religion, freedom from want, and freedom from fear - established a political programme not only for the USA and other world powers but also for pacifist and other social movements. It sought to relate the issue of human rights to the 'New Deal' of the 1930s, a period when the meaning of 
human rights was still undefined. Roosevelt's understanding, also set out in the Atlantic Charter (1941) and his speech resulting from the Second Bill of Rights (1944), served to align human rights with social welfare policies, including the right to self-determination, as well as social and economic rights. This approach was also meant to result in a new post-war international organisation, along the lines of the League of Nations, in which the USA would play a prominent role.

However, as noted by Moyn (2010), the political consequences of the war and the rapid changes in US foreign policy after Roosevelt's death in 1945 altered this understanding. Although human rights played an important role in the formation of the UN, including the establishment of the Commission on Human Rights as early as 1946, efforts to institutionalise them were less important. Therefore, the understanding of its meaning would go through a drainage process, evident in the neglect of principles such as self-determination and the greater emphasis on social and economic rights, previously considered important due to the tragic effects of Nazism. More than just a strategy for uniting allies around a common enemy, the UDHR also embodied strategic devices resulting from the complex interactions of political forces. For example, on the one hand, the British prime minister, Winston Churchill, emphasised the application of the principle of self-determination to territories formerly occupied by Germany alone, thereby sparing the other European empires. On the other, Churchill and other leaders sought to reduce the weight given to social and economic rights, a move aimed at blocking their possible association with socialist and communist ideals (Moyn 2010).

As a result, the negotiators - including renowned political personalities such as John P Humphrey, Eleanor Roosevelt and René Cassin - were largely willing to serve interests that were already tied to the emerging logic of the Cold War - more specifically, interests that were guided by European conservatism and the Truman Doctrine, entrenched in the late 1940s to contain Soviet expansion (Moyn 2010). Not surprisingly, the process of drafting the UDHR was strongly influenced by efforts to associate it with the Declaration of Human and Citizen Rights, promulgated in France in 1789, and the US Declaration of Independence of 1776. Both these juridical-political statements expressed the assumptions $18^{\text {th }}$ century liberalism, and were designed to organise a social, political and economic structure consistent with the rise of industrial capitalism.

The political reading that prompted this position was based on the claim that, after the war, the close association of human rights with the welfare state as foreseen by Roosevelt could elevate the principle of equality to the same level as the principle of freedom. This could give economic and social rights greater prominence in the UDHR. Given that this could favour the discourses and adages of communism, most members of the Commission on Human Rights worked to reduce the emphasis on social equality.

The reaction of the Soviet bloc clearly demonstrated the clash of power. These confrontations marked the political struggles around the production of truth - a process of veridiction - and the definition of 'human rights.' Thus a member of the socialist Yugoslav delegation declared: 
[T] he Declaration had not gone further than the old concepts, and the Yugoslav delegation regretted that the continuous efforts of certain delegations, and in particular those of the USSR delegation with which the Yugoslav delegation concurred, had not found, in that respect, sufficient understanding on the part of the majority of the Committee; many proposals, which would have given the declaration a progressive and decisive character, had been rejected [...] In the new part of the declaration dealing with the proclamation of social rights, particularly in respect to social rights which should be recognized so as to protect man against the system exploiting him in the social capitalist order, the draft was in a great measure inadequate. (United Nations 1948a: 915).

In the course of negotiations up to the end of 1948, the key issue was to establish correlations between the Declaration's prescriptions and the two polarities of the Cold War, namely the doctrines of capitalism and communism, and led by the USA on the one hand and the Soviet Union on the other. Essentially, both sides tried to turn their political doctrines into universal values.

All this came to a head when the Soviet bloc (comprising Belarus, Yugoslavia, Poland, Czechoslovakia, Ukraine and the Soviet Union) effectively rejected the Declaration by abstaining during the final vote. This not only signalled the defeat of the bloc, but also highlighted the political parameters that constrained the definition of supposedly universal human rights.

As a result, as pointed out by Alves (2011), the Declaration was divided into seven sections, comprising 'personal rights' (articles 2, 3 4, 5, 6, 7 and 15); 'legal rights' (articles 8, 9, 10, 11 and 12); 'civil liberties regulations' (articles 13, 18, 19 and 20); 'subsistence rights' (Article 25); 'economic rights' (articles 17, 22, 23 and 24); 'social and cultural rights' (articles 26, 27 and 28); and 'political rights' (articles 21 and 29). This created a document that privileged personal, legal, civil and political rights (although excluding the right to self-determination), and did little to address social and economic rights. The last section also included the explicitly liberal 'right to private property.'

Seen from this perspective, the Declaration ignored social and cultural diversity by giving a restricted meaning to human rights, based on the citizenship arising from Western bourgeois revolutions. According to Ramina and Friedrich (2018), it was only approved without any opposing votes because it was drafted as a declaration, and was therefore not legally binding. Consequently, it was strongly criticised as a political instrument for protecting the global viability of the capitalist system.

Due to these controversies and a long subsequent period of paralysis, as analysed by Douzinas (2000) and Moyn (2010), it was only from the mid-1970s, with the Cold War waning and the first signs of the collapse of the socialist system, that the UDHR, as the largest legal-political record of human rights, finally triumphed. In a context of successive postcolonial wars, the emergence of authoritarian regimes, increasing migratory flows, and violations caused by deepening pauperisms, this was due to the prevalence 
of discourses and practices in favour of the defence of humanity - that is, discourses and practices that led to the unification of antagonistic ideologies around 'human values', nullifying the idea of reform and institutional transformation within the liberal and capitalist regimes.

Practices prescribed to humankind were increasingly regulated, which, in parallel with the traditional exercise of international relations, turned the conditions of human existence into an interest to be addressed by political actions from the local to the transnational spheres. From the moment that a characterisation of the human was universally fixed as an effect of world war - the possible annihilation of life on earth - the UDHR became an important act of veridiction that legitimised a new set of legal-political devices aimed at taking care of the planet's populations (Passetti 2013). The end of the $20^{\text {th }}$ century saw the emergence of new protocols, concepts, treaties and programmes under the UN umbrella and directly related to the UDHR, such as the notions of human security and a culture of peace, the principle of responsibility to protect, and the Millennium Development Goals (MDGs).

This allows us to view the UDHR as part of a process of veridiction that has consolidated a way of life for the peoples of the world - a set of principles that could justify political interventions aimed at preventing 'threats' against human rights, calculating risks and losses, disposing of wealth and pauperism, equating deficits and surpluses, managing displacements, mitigating vulnerabilities, and selectively pacifying conflicts; all seen as necessary for containing threats to humankind. These goals began to demand transterritorial actions to produce a useful, docile and safe life, with all its biopolitical implications.

\section{Reshaping biopolitics}

The 70th anniversary of the UDHR has highlighted the growing debate about rights issues plus a range of approaches to enhancing their importance, stressing, for example, the character of the transnational solidarity it supposedly fosters (Proner et al 2018). It is particularly interesting to note the prominence of revisionist perspectives aimed at rediscovering the true meaning of the concept of human rights, so that its use could produce positive results. This includes Moyn's arguments (2018) about the results of the global application and expansion of human rights since the 1970s. Underpinned by extensive research, they show how the human rights movement and its main normative guideline, the UDHR, have taken a wrong turn by underestimating social and economic rights. Seen from this perspective, the UDHR has failed, rather than succeeded, to reverse massive violations of human rights.

These analyses also show how the UN standard for human rights has worked to obstruct some key discussions in the political arena, notably about inequality. However, from the perspective that human rights operate a technology of power directed at life in a broader sense, it is possible to widen the range of criticism by viewing the UDHR as part of the emergence of a new governmentality that resizes biopolitics. Foucault $(2005,2008)$ used the notion of governmentality to describe measures aimed at governing men and 
women understood as a 'body' or 'species', characterised by intrinsic properties such as 'health conditions,' 'skills,' 'intellectual abilities', and so on. But how can the UDHR be seen to reshape biopolitics as a global governmentality?

As argued by Passetti $(2011,2013)$ and Rodrigues (2012), the UDHR disregards local practices in the name of a universal truth (the validity of human rights), by operating as a means of establishing models and parameters for the conduct of individuals (national citizens, but also 'global citizens') and states (that must observe rules related to the protection of human rights). If, as claimed by Foucault (1982), governing is the capacity to direct conduct, the production of a set of rules based on the UDHR has established a pattern for 'good' and 'correct' ways to proceed as an individual or state towards 'humans.' However, is every human being a subject of rights?

According to Agamben (1998), human rights must be analysed as eternal and meta-juridical values that, through their biopolitical character, distinguish not only between citizens and non-citizens, but also between humans and inhumans. Despite their universal formulation, this makes human rights discourses and practices operate in a selective and hierarchical logic that distinguishes between the most human and the less human or less than human because of their conduct and values. Therefore, an appraisal of human rights necessarily involves the monitoring of human practices as well as judgments regarding them - both formal, as in international courts such as The Hague, and informal, based on ethical assumptions reflected in social media and mainstream global media. While the UDHR does not have mandatory bonds, constructing a moral configuration based on universalised liberal values has placed value-based constraints on individuals, corporations and states with unequal power, and unequal abilities to impose a way of living in accordance with human rights principles.

It is instructive to note the enormous gap between the emergence and global affirmation of human rights about 40 years ago and the spectacular sequence of violent conflicts in this same period. Somalia (1991), Rwanda (1994) and Srebrenica (1995) are leading examples of 'humanitarian' interventions by Western and non-Western countries, with 'human security' and the 'responsibility to protect' as their banner. Aimed mainly at countries in the Global South, these interventions have combined military forces; international organisations and subsidiary agencies, such as the African Union, UN, UNDP, FAO and UNICEF; multinational corporations; religious relief organisations; and NGOs (such as Médicins sans Frontières and the Red Cross). Activated under the pretext of protecting populations exposed to situations of precarity, authoritarianism and institutional bankruptcy, these interventions have succeeded in containing certain crises, but have hardly built states or protected human rights (Siisiäinen 2019).

According to Gros (2010), empirical data shows how human rights are used as a political strategy - selective and utilitarian - aimed at the contingency of the ruin of institutions that produce alleged situations of misrule; civil and ethnic wars, terrorism and illegal cross-border trafficking; migratory flows towards the great global metropolises; and the possible spread of epidemics and health vulnerabilities. In other words, it shows how human rights are 'defended' through procedures, discourses and practices aimed at con- 
trolling certain populations; regulating their living conditions; and managing poverty and its social and environmental effects.

The human rights discourse and practice ostensibly operate a logic of defending humanity. However, this goal should not be understood as an unrestricted and positive investment in the lives of all humans on the planet. Rather, it reprises the old division between the civilized and colonial worlds into a new logic of segmentation, with the emergence of another dualism between liberal and non-liberal societies. This political arrangement, as Fernández (2018: 520) has shown, performs a 'provincialisation of human rights' through selective humanitarian actions aimed at exporting liberal institutions, especially throughout the postcolonial world: fragments of the world that are considered outside the civilizational order, but could be included if they were reshaped by liberal values, norms and institutions. The UDHR and its correlate declarations are part of this global device that seeks to universalise a general pattern for human and institutional conduct towards one another.

A good example is the programme associated with the Millennium Development Goals (MDGs), a recent protocol drawn up by the UN in harmony with the UDHR. Adopted at a 2000 UN World Summit, the MDGs comprised eight goals to be met by 2015 in order to create a less inequal and more sustainable world (UNDP 2015). In 2005, the UN Millennium Project - an institutional platform designed to accompany and support the MDGs - introduced the concept of 'changing the world' as one of the MDG's strategic interests. It listed the 'key elements of adequate human capital' as the 'means to [achieve] a productive life.' It is interesting to note how the lives of people previously exposed to extermination and annihilation have been re-signified as potentially productive ones in a globalised and post-industrial global economy. In this sense, being 'human' in an era of global rights becomes connected with being economically active in a digital global economy.

It seeks to stimulate new forms of people's subjectivity, constantly adapted to productive inclusion in this global economy. The new process of subjectification is not the same as that analysed by Foucault at the dawn of the current capitalist era. At the end of the $18^{\text {th }}$ century and the beginning of the $19^{\text {th }}$, the 'disciplines of the body' played a key role in educating people to become useful and harmless (Foucault 1995). Various disciplinary tactics were applied to humans in confinement situations (factories, prisons, schools, hospitals and families, among others), and the final goal was to produce manageable/governable people. However, in times when, according to Gilles Deleuze (1992), the societies of discipline have been gradually overcome by societies of control, in which the electronic economy connects markets and governmental practices on a global scale, the concept of 'productive human being' has changed significantly. More than a disciplined person, the actual society of control seeks to produce resilient people, i.e., individuals who can adapt to changing circumstances, always aiming at adding value to the globalised economy. The concept of resilience, taken from the physics of materials, is one of the most frequently used current metaphors, defining a person who can be 'deformed' by an action and, instead of rebelling against it, decides to reshape himself/herself in order to be regarded as a productive human being. The very conception of human being, in a neoliberal pattern, is reframed as one who can produce and consume goods (Foucault 2008). 
However, as in the first and second Industrial Revolutions, not everybody can be included in the capitalist economy, due to its immanent limitations for inclusion or frontal opposition to it. During the 'societies of discipline' (Foucault 1995), the combination of biopolitical practices (policies on urbanisation, social health, sanitation, etc) and disciplines (the training and education of individual bodies) had 'positive' features, since they were meant to 'produce' conducts, ideas, civil and political rights, and a healthier environment for the 'useful and harmless.' For those who remained indomitable, the industrial societies saved special instruments such as the police, the prisons system, expulsion, and physical elimination. The current society of control has kept the characteristic of combining a universal and inclusive discourse with practices of segregation, violence, and the extermination of those who cannot be included in a global and digital economy. This is also the era when the human rights discourse is propelled by the unfolding of initiatives such as the MDGs.

Following Mbembe (2003), it should be noted that the ambivalent feature of a global biopolitics - in this dynamic, arranged by the human rights of inclusion as well as segmentation - is not far removed from the production of the 'barbarian' alterities during colonial times. New forms of inclusion and exclusion have been assembled within societies, and among countries and continents. On the one hand, global cities - metropolises integrated with global capitalism (Sassen 2001) - have neighborhoods that are totally connected with similar urban formations in the North and the Global South; on the other, they have segregated and impoverished zones controlled by the military, police forces, or private security companies behaving more like military assault troops with each passing day (Graham 2010).

According to Mbembe (2003) and Agamben (1998), new practices, norms, and exceptions work to define which lives must be potentiated and which deaths can be neglected or, even worse, enacted. Although articulated in the field of subjectivities (since they also refer to the UDHR guidelines), such definitions, which have grown dramatically since the legal and security reactions to the 9/11 terrorist attacks in the USA, now authorise the normalisation of states of exception. Consequently, by demanding the defence of human rights - that is, the defence against 'atrocities' and 'barbarism' - it is possible to normalise intrusions into private life, the proliferation of electronic devices for biometry, the production of databases with personal features, the justifications for extrajudicial assassinations or prison facilities (such as US base of Guantánamo in Cuba), and the legitimacy to attack countries with or without UN authorisation.

Mbembe (2003) uses the category of 'necropolitics' to show how in some spaces a reshaped colonial occupation takes place propelled by the non-stop production of 'enemies' of humanity, people that are deprived from their status of 'humanity' by being considered threats to 'universal values' condensed in the UDHR. Thus, the basic biopolitical mechanism of providing life for the productive while controlling or exterminating the non-productive or/and threatening reaches a global scale, operating both inside and outside state borders. This mechanism of global biopolitics, however, runs under new modulations, beyond the limits of political sovereignty, thereby promoting, among the populations of 
the globe, the defence of the standard humanity that must be pursued. It is, therefore, a dimensioning and adaptation of biopolitics in the face of cosmopolitanism and the transterritorial flows of financial, technological and digital capitalism which rearticulates the imperative of eliminating the biological dangers posed by the Unhuman (terrorists, drug-traffickers, pirates, insurgents etc.). The 'Peace on Earth' promised after World War I and transplanted on to the UDHR must be pursued by the promotion of values (liberal democracy, neoliberal entrepreneurism, sustainability, resilience) that combats 'barbarian acts that jeopardize the conscience of humanity').

As a result, beyond the debate about the lack of rights or the fragility of the enforcement of human rights, it is important to realise how the formulation of human rights itself - and their position as the current global pattern for a prosperous life on the planet - is a crucial tool for managing a global order based on a set of values with human rights supposedly at its core. In this sense, following Moyn (2010), it can be argued that human rights block the political questioning of capitalism, since it has reached the level of a new utopia which could be achieved with the humanisation of the global economy. Therefore, the demand for and application of human rights goes further, constantly acting to dissolve resistance. This is because the emergence of various states of violence (Gros 2010) in contemporary times produces 'barbaric' alterities such as 'the terrorist' which reduce all forms of obstacles to the realisation of global capitalism to abnormalities and threats.

In this context, the UDHR should be analysed not as the consummation of universal and immanent values, but as the powerful effect of a process of veridiction that emerged after World War II, claiming a representation of humanity by forging a sense of unity, solidarity and affectivity among humans. Therefore, the UDHR is a document that allows us to enter a global biopolitics aimed at controlling while promoting a standardised way of life adapted - or resilient - to the reproduction of global capitalist economy and the institutionalisation inspired by liberal democratic arrangements. By seeing the UDHR through the lenses of Foucauldian concepts such as 'veridiction', it is possible to avoid the naturalisation of human rights - as if they were the consubstantiation of a previous and universal 'Truth' - and, by doing so, to understand it as a powerful instrument in the contemporary global definition of how to live and how to die.

\section{Final remarks}

In times like ours, when right-wing parties have gained traction, fascist-like leaders have been elected, nationalist xenophobia has grown, migrants and refugees have been murdered, imprisoned and violated, and poverty is on the rise, is it ethically legitimate to criticise human rights in general and the UDHR in particular? Does a critical perspective on human rights constitute support for - or conniving with - the massive violation of human dignity? We don't think so. On the contrary, it is possible to foresee inventive ways of igniting struggles around human rights, avoiding the many 'captures' - to use a Deleuzean term (1992) - that neutralise the liberating power of human rights. 
Reflecting on the possibility of performing a Foucauldian analysis of human rights, Ben Golder (2015) assumed the risks and the difficulties to think about the 'human' and 'rights' taking such an iconoclastic author as Michel Foucault. The most obvious obstacle would be to overcome the visceral Foucauldian critique of the 'sovereign subject and [the] individualist ontology' (Golder 2015: 6). The Foucauldian genealogy of power and his later work on ethics and the aesthetic of the self (Foucault 2003, 1978) demolished claims of a 'human nature' from which any kind of right or prerogative could be derived. For Golder, most of Foucault's critics were unable to understand the apparent paradox between his philosophy and his political activism, in movements such as the Groupe d'Information sur les Prisons (Group for Information on Prisons, or GIP), in the early 1970s, or his controversial analyses of the Iranian Revolution at the end of that decade (Ghamari-Tabrizi 2016). The militant Foucault seemed to be engaged with a liberal and human rights rhetoric, while the philosopher Foucault was dedicated to destroying the ground on which the liberal order had been erected.

According to Golder, this is a false problem, because Foucault has shifted the very ground for the debate about human ontology, subjectivity and the production of truth. According to Golder, Foucault did not deny the existence of a human ontology or subjectivity; instead, he rejected the notion of a universal ontology and subjectivity - in other words, everybody is provided with a 'personality', a 'set of values', an 'image of himself/ herself' (Golder 2015: 20-21). However, this 'personality' is forged within a myriad of subjective forces, such as the 'discipline technologies', moral values etc., in a process that does not exclude the agency of the individual, who could resist the imposition of some values or forms of conduct (Foucault 1982).

This is why, according to Foucault, the subjectivation process should be seen as a form of combat, a struggle, in which modelling forces clashes with individual reactions, with no foreseeable outcome. That is also why it is possible to read Foucault's later work as a claim for the rebellion against the modelling forces and the cultural, social, political and economic patterns that forge a manageable individual (useful and harmless). In other words, the assumption that human subjectivity is not derived from a natural and invariable source opens the possibility for everyone to act upon himself/herself, in an infinite process of building oneself (the process Foucault called the 'aesthetic of existence'). In this sense, for Golder (2015), when Foucault made use of the liberal vocabulary of human rights, it did not mean that he had been converted to liberalism, or was repudiating his earlier work. Instead, he sees in Foucault's late work the elaboration of a 'counter-conduct' strategy in which the language and institutions devoted to human rights could operate to enhance local struggles for liberation. For example, the defence of prison inmates' human rights could lead to a broader critique of penal justice, or embracing human rights rhetoric could empower claims for freedom and for protection against authoritarian regimes.

We are not invoking a Foucauldian critique - related to an anti-contractualist tradition - to dismiss the UDHR as a whole, but to help us understand the Declaration in context, as the result of power correlations in a process of veridiction. Recognising the historicity of the UDHR does not amount to abandoning the political possibilities that 
the struggle for human rights should enable. On the contrary, it assumes the political and historical contingency of the UDHR in order to avoid its operationalisation as a new tool for a postcolonial colonialism in the form of a global necropolitics (Mbembe 2003). In this perspective, the UDHR should not be regarded as a universal panacea, nor a global evil tool, but the historical outcome of complex clashes among political interests, each fighting to impose its 'truth' (vérité) about the world. If politics is warfare, as Foucault confirms, human rights are part of this perpetual combat. The meaning and direction of a set of concepts or values such as the UDHR are established in the course of battles among governments over the fates of peoples and world affairs. A Foucauldian critique of the septuagenarian declaration is not a declaration of war against it, but a declaration that the UDHR is a weapon that can be claimed by many warriors.

\section{Notes}

1 In his genealogical analysis of power, Foucault defines 'device' as: a) a heterogeneous set from which nexus are established between discourses, practices, institutions, laws, scientific statements, administrative measures, philosophical propositions, etc; b) a field of rationalities that responds to an urgency, always with a strategic function; c) a crossing between power relations and knowledge relations (Foucault 1994: 299300).

2 The International Committee of the Red Cross was directly responsible for the international agreement that resulted in the Geneva Convention (1864), which is attributed to Henri Dunant (founder in 1863 of the ICRC) and regarded as the first initiative in International Humanitarian Law.

3 'No black state, not even the Republic of Liberia, has acceded to the Geneva Convention; nor is it desirable for them to do so, because the black peoples of Africa are, for the most part, still too savage to be able to associate themselves with the humanitarian thinking that inspired this treaty and put it into practice' (La Croix-Rouge 1880: 5, translated by the authors).

4 'The UDHR sets out a number of principles found in the Red Cross Conventions. [...] The principle of equality of all human beings, contained in Articles I and II of the Declaration, finds its equivalent in the draft Convention, as does the prohibition of all discrimination based on nationality, race, confession or other similar criteria. [...] The first Geneva Convention of 1864 is certainly the most illustrative example of this idea, as it orders treating all wounded and sick in the same way, whether friends or enemies. [...] The right to life and liberty, which the Declaration enshrines in its Article III, is also contained in the Humanitarian Conventio' (La Croix-Rouge 1949: 252-258, translated by the authors).

5 The two International Human Rights Covenants derived from the UDHR (on economic, social and cultural rights and on civil and political rights) were adopted by the UN General Assembly in 1966, but only became opereative in 1976.

6 The concept of human security first emerged in the UN Human Development Report published in 1994, entitled New Dimensions of Human Security. It has three central features: protecting people from vulnerabilities arising from underdevelopment; keeping them safe from chronic threats such as hunger and disease (freedom from want); and protecting them from sudden and harmful changes in the patterns of everyday life as a result of physical violence from wars, genocide and ethnic cleansing (freedom from fear). It places the individual at the centre of actions aimed at preserving or restoring international security, thus broadening the conception of global civil society.

7 Drafted in 2001 by the International Commission on State Intervention and Sovereignty (ICISS), the concept of Responsibility to Protect (R2P) is linked to the idea that state sovereignty entails responsibilities, and if such an entity is unwilling or unable to guarantee them, the principle of non-intervention gives way to the international responsibility to protect. In this sense, a resignification of sovereignty as 'authority' (over a given territory and its population) is made in favour of sovereignty as 'responsibility' (which can be questioned if there is no guarantee of 'minimum' human rights standards). 
8 These were defined as basic nutrition; a health system that enables people to live a long and healthy life; sexual and reproductive health; Literacy, numeracy, and marketable skills for $21^{\text {st }}$-century jobs; technical and entrepreneurial skills to adopt existing but underused technologies; and scientific expertise to advance new knowledge (United Nations 2005).

9 A reference to the Preamble of the UDHR (United Nations 1948b).

10 The concept of revolt aligns with the reflections of Albert Camus (2007). It differs from the notion of revolution, which recomposes authorities; understands violence in terms of an awareness that we live an absurd political existence; and affirms other possibilities of human existence in the course of interrelated rebellions and political struggles.

\section{References}

Agamben, G. 1998. Homo Sacer: sovereign power and bare life. Stanford: Stanford University Press. Anghie, A. 2007. Imperialism, sovereignty and the making of international law. Cambridge: Cambridge University Press.

Alves, J A L. 2011. Os direitos humanos como tema global. Brasília: Funag.

Bonditti, P, D Bigo and F Gros (eds). 2017. Foucault and the Modern International: Silences and Legacies for the Study of World Politics. New York: Palgrave Macmillan.

Camus, A. 2007. L'homme revolte. Paris: Gallimard.

Clausewitz, C V. 2007. On war. Oxford: Oxford University Press.

Comparato, F K. 2013. A afirmação histórica dos Direitos Humanos. São Paulo: Saraiva.

Deleuze, G. 1992. 'Postscript on the Societies of Control.' October 59: 3-7.

Douzinas, C. 2000. The end of human rights. Oxford: Hart Publishing.

Duarte, J P. 2019. Governar a humanidade na guerra e na paz: uma genealogia das organizações não governamentais de direitos humanos na segurança internacional. $\mathrm{PhD}$ thesis. Pontifícia Universidade Católica de São Paulo (PUC-SP), Brazil.

Fernández, M. 2018. 'Um Olhar Decolonial sobre os Direitos Humanos.' In C Proner, H Olasolo, C V Durán, G Ricobom and C Back (eds), $70^{\circ}$ Aniversario de la Declaración Universal de Derechos Humanos: la protección internacional de los derechos humanos en cuestión. Valencia: Tirant Lo Blanch.

Foucault, M. 1978. History of Sexuality - Vol. I. New York: Pantheon Books.

1982. The Subject and Power. Critical Inquiry 8 (4): 777-795.

1994. Dits et écrits III (1976 - 1979). Paris: Gallimard.

1995. Discipline and Punish: The Birth of the Prison. New York: Vintage Books.

2003. Society Must Be Defended. New York: Picador.

2007. Security, Territory, Population. London: Palgrave Macmillan.

2008. The Birth of Biopolitics. London: Palgrave Macmillan.

2019. O enigma da revolta: entrevistas inéditas sobre a Revolução Iraniana. São Paulo: N-1.

Ghamari-Tabrizi. 2016. Foucault in Iran: Islamic Revolution after the Enlightenment. Minneapolis: Minnesota University Press.

Golder, B. 2015. Foucault and the Politics of Rights. Stanford: Stanford University Press.

Graham, S. 2010. Cities Under Siege: new urban militarism. London: Verso. 
Gros, F. 2010. States of violence: an essay on the end of war. London: Seagull.

Gumpert, M. 1944. História da Cruz Vermelha. Rio de Janeiro: Ocidental.

Henkin, L. 1990. The Age of Rights. New York: Columbia University Press.

Hobbes, T. 1968. Leviathan. London: Penguin Books.

Hunt, L. 2008. Inventing Human Rights: A History. New York: W. W. Norton \& Company.

Kolb, R. 1998. 'The relationship between international humanitarian law and human rights law: a brief history of the 1948 UDHR and the 1949 Geneva Conventions.' International Review of the Red Cross 324: 1-8.

La Croix-Rouge. 1880. 'La Croix-Rouge chez les nègres' Bulletin International des Sociétés de Secours aux Militaires Blessés 41.

1949. 'La Déclaration Universelle des Droit de L'Homme et les conventions internationales protégeant les victimes de la guerre.' Bulletin International des Sociétés de la Croix-Rouge, Quatre-vingtiène annèe. T. LXXX.

Mbembe, A. 2003. 'Necropolítics' Public Culture. Durhan: Duke University Press.

Moyn, S. 2010. The last utopia: human rights in history. Cambridge and London: Harvard University Press.

2018. Not enough: human rights in an unequal world. Boston: Harvard University Press.

Mutua, M. 2001. 'Savages, Victims, and Saviors: The Metaphor of Human Rights.' Harvard International Law Journal 42 (1): 201-245.

Passetti, E. 2011. 'Ecopolítica: procedências e emergência.' In G Castelo Branco and A Veiga-Neto (eds), Foucault: filosofia e política. Belo Horizonte: Autêntica, pp. 127-141.

2013. 'Transformações da biopolítica e emergência da ecopolítica.' Ecopolítica 5: 1-36.

Proner, C, H Olasolo, C V Durán, G Ricobom and C Back (eds). 2018. 70 Aniversario de la Declaración Universal de Derechos Humanos: la protección internacional de los derechos humanos en cuestión. Valencia: Tirant Lo Blanch.

Proudhon, P J. 1998 [1861]. La guerre et la paix (vols. I e II). Antony: Éditions Tops/H. Trinquier.

Ramina, L and T Friedrich. 2018. 'A Declaração Universal dos Direitos Humanos e seus Vícios de Origem.' In C Proner, H Olasolo, C V Durán, G Ricobom and C Back (eds), 70 Aniversario de la Declaración Universal de Derechos Humanos: la protección internacional de los derechos humanos en cuestión. Valencia: Tirant Lo Blanch.

Rodrigues, T. 2010. Guerra e política nas relações internacionais. São Paulo: EDUC.

2012. 'Segurança planetária, entre o climático e o humano.' Ecopolítica 3: 5-41.

Sassen, S. 2001. The Global City: Tokyo, New York, London. Princeton: Princeton University Press.

Schindler, D. 1979. 'Le Comité international de la Croix-Rouge et les droits de l'homme.' Revue Internationale de la Croix-Rouge 715.

Siisiäinen, L. 2019. Foucault, Biopolitics and Resistance. London and New York: Routledge.

United Nations. 1948a. Hundred and eighty third plenary meeting. Continuation of the discussion on the draft of UDHR (A/777), 915. At https://undocs.org/en/A/PV.183 [Accessed on 22 February 2019]. . 1948b. The Universal Declaration of Human Rights. United Nations, General Assembly resolution 217-A. At https://www.un.org/en/universal-declaration-human-rights/ [Accessed on 22 June 2019]. 
2005. 'The means to a productive life.' Investing in Development: a practical plan to achieve the Millennium Development Goals. UN Millennium Project. At http://siteresources.worldbank.org/ INTTSR/Resources/MainReportComplete-lowres[1].pdf [Accessed on 22 May 2019].

Walker, R B J. 1992. Inside/Outside: International Relations as political theory. Cambridge: Cambridge University Press.

2012. After the Globe, Before the World. London: Routledge.

\section{About the authors}

Thiago Rodrigues is an associate professor at the Institute for Strategic Studies (INEST/ UFF), Brazil. He is the director of the research network "Security and Defense in the Americas” (SeDeAMERICAS), www.sedeamericas.com; Twitter: @DefenseAmericas. He is also an invited professor at the MBA on International Relations at FGV, a columnist on drug policies for Carta Capital, director of institutional relations of Brazil's Defense Studies Association (ABED) and a board member of the think-tank CRIES (Argentina). Rodrigues holds a Ph.D. in Political Science from PUC-SP (Brazil) and Sorbonne Nouvelle (France). His latest publications, in collaboration, include 'Mano Dura y Democracia en América Latina' (América Latina Hoy, 2020), 'México y el narcoanálisis' (Colombia Internacional, 2019) and 'Brazil: Violence and Public (un)Safety' (in Violence in the Americas, 2018).

Tadeu Maciel is a collaborating assistant professor and postdoctoral fellow (PNPD/ CAPES scholarship) of the Graduate Program of Strategic Studies of Fluminense Federal University (UFF). He is a research fellow of the Brazilian Foreign Policy Studies Laboratory (LEPEB/UFF), the International Organizations and Global Themes Research Group (OITEG/UFABC) and the Laboratory of Analysis in International Security and Monitoring Technologies (LASInTec). He is the head of the research laboratory NEXUS: security and development in global politics (INEST/UFF). He holds a Ph.D. in Humanities and Social Sciences from the Federal University of ABC (UFABC), with an internship at the National University of Quilmes (UNQ). Previously, he was an assistant professor (20112015) and head (2013) of the undergraduate course in International Relations at Santa Marcelina College. His latest publications, both in collaboration, are 'The security-development nexus on post-Cold War' (EGN 2019) and 'Pacification in the Brazilian way? The Caxias Paradigm, the Minustah and the Jair Bolsonaro's Government' (ABED 2019).

João Paulo Duarte is an associate professor of International Relations of Paulista University (UNIP). He holds a Ph.D. (2019) and an M.A. (2011) in International Relations from the Graduate Studies Program in Social Sciences of the Pontifical Catholic University of São Paulo (PUC-SP), both with CNPq scholarships. He was a Ph.D. sandwich fellow (2017) of the University of Geneva, under a Capes scholarship. Duarte is a research fellow of the Laboratory of Analysis in International Security and Monitoring Technologies (LASInTec), linked to the Department of International Relations of the Federal University of São Paulo (UNIFESP). 


\section{Paz Forjada pela Guerra: A Declaração Universal dos Direitos Humanos 70 Anos Depois}

Resumo: A recente celebração da Declaração Universal dos Direitos Humanos (DUDH), realizada em dezembro de 2018, levantou a necessidade de problematização de suas diretrizes e de seus efeitos políticos nos tempos contemporâneos. Apropriando-se da abordagem genealógica de Michel Foucault ao poder, este artigo analisa a inscrição normativa da DUDH como o surgimento de um dispositivo político-jurídico que compõe novas modulações da biopolítica. Nesses termos, um dispositivo que, ao fixar o conteúdo dos direitos humanos, não se baseia na paz como é comumente localizado - mas na reinscrição permanente da guerra, às vezes em dimensões que vão além das limitações da soberania.

Palavras-Chave: Declaração Universal dos Direitos Humanos; política como guerra; biopolítica; reinscrição da guerra; análises foucaultianas.

Received on 3 September 2019, and approved for publication on 10 March 2020. 